\title{
FAKTOR YANG MEMPENGARUHI IMPULSE BUYING
}

\author{
Gilang Pratama Hafidz, Fachmi Tamzil \\ Fakultas Ekonomi dan Bisnis Universitas Esa Unggul \\ Jalan Arjuna Utara No 9 Kebon Jeruk Jakarta 11510 \\ gilang.pratama@esaunggul.ac.id
}

\begin{abstract}
The change in buying style from offline to online has made many modern retailers unable to compete, thereby reducing sales massively in shopping centers. This situation encourages industry players to be able to find a breakthrough in increasing sales at their outlets. This study aims to determine the factors that can increase impulse buying so that it can provide an empirical basis for decision making by retailers to increase their sales intensively. Primary data were collected as many as 360 respondents with purposive sampling using a questionnaire. The hypothesis is tested using the structural equation modeling method. Based on the statistical test output, it is concluded that buyers who shop offline can shop immediately when they feel positive emotion which is influenced by the influence of the social environment and the appearance and visual merchandising of their shopping outlets. From this research, it is also found that consumers do not involve product involvement, product knowledge and social lifestyle in making purchases. This research is limited to the distribution and demographic clusters that are not broad, further research is needed to provide a more comprehensive empirical basis.
\end{abstract}

Keywords: Impulse Buying, Visual Merchandising, Product Involvement

\begin{abstract}
Abstrak
Perubahan gaya beli dari offline menjadi online membuat banyak ritel modern kalah bersaing sehingga menurunkan penjualan secara massive di pusat-pusat perbelanjaan. Situasi tersebut mendorong pelaku industri untuk dapat menemukan breakthrough dalam meningkatkan penjualan pada outlet-nya. Penelitian ini bertujuan untuk mengetahui faktor-faktor yang dapat meningkatkan impulse buying sehingga dapat memberikan landasan empiris dalam pengambilan keputusan oleh pelaku usaha ritel untuk dapat meningkatkan penjualannya secara intensif. Data primer dikumpulkan sebanyak 360 responden dengan purposive sampling menggunakan kuesioner. Hipotesis diuji menggunakan metode structural equation modelling. Berdasarkan output uji statistic, disimpulkan bahwa pembeli yang berbelanja secara offline dapat berbelanja secara seketika saat merasakan positive emotion yang dipengaruhi oleh pengaruhi lingkungan sosial dan tampilan serta visual merchandising outlet perbelanjaannya. Dari penelitian ini didapatkan juga bahwa konsumen tidak melibatkan product involvement, product knowledge dan social lifestyle dalam melalukan pembelanjaan. Penelitian ini terbatas pada sebaran dan klaster demografi yang tidak luas, penelitian lanjutan dibutuhkan guna memberikan landasan empiris yang lebih komprehensif.
\end{abstract}

Kata kunci: Impulse Buying, Visual Merchandising, Product Involvement

\section{Pendahuluan}

Dalam era global ini mulai banyak bermunculan perusahaan - perusahaan ritel di Indonesia. Dengan meningkatnya penjualan ritel modern yang ditaksir menembus Rp256 triliun pada 2019, atau tumbuh sekitar $10 \%$ dari realisasi tahun sebelumnya. Berdasarkan data Aprindo, nilai penjualan ritel modern pada 2016, 2017, dan 2018 berturut-turut mencapai Rp205 triliun, Rp 212 triliun, dan Rp233 triliun.
Hal ini di tunjang dengan pertumbuhan daya beli masyarakat. Menurut Euromonitor, Indonesia adalah salah satu negara yang pasarnya tumbuh dengan kelas menengah potensial terbaik untuk 2015-2020. Indonesia punya jumlah kelas menengah nomor empat terbesar di dunia dengan 17,3 juta rumah tangga pada 2014, hanya kalah oleh Amerika Serikat, India, dan yang terbesar tentu Cina. Selain besarnya jumlah keluarga kelas 
menengah, Indonesia potensinya besar karena kekuatan membelinya menguat, yang memungkinkan mereka berbelanja lebih leluasa. Perkiraan Euromonitor International menyebutkan rata-rata pendapatan bersih orang Indonesia per rumah tangga mencapai $\$ 11.300$ (sekitar Rp150 juta per tahun), naik dari sekitar $\$ 6.300$ dibandingkan pada 2014.

Pada 2020, Boston Consulting Group (BCG) memproyeksikan akan ada sebanyak 117,5 juta penduduk Indonesia yang masuk dua kategori dengan pengeluaran belanja yang besar. Deloitte, salah satu konsultan keuangan di Indonesia menyatakan terdapat tiga kategori obyek belanja teratas rumah tangga, yakni makanan, rumah dan peralatan, serta pakaian. Belanja pakaian masuk dalam prioritas ke-3 untuk masyarakat yang punya pengeluaran Rp2-3 juta, yakni sebesar 11 persen dan 9 persen untuk masyarakat yang pengeluarannya Rp3-5 juta. Artinya, individu yang masuk kelompok Rp2-3 juta akan membelanjakan uangnya sebesar Rp220-330 ribu per bulan untuk pakaian. Sedangkan masyarakat dengan kelompok Rp3-5 juta akan membelanjakan uang sebanyak Rp270-450 ribu per bulan.

Kegiatan berbelanja tersebut menjadi peluang besar bagi para pelaku usaha pusat perbelanjaan dan peritel modern. Namun pertumbuhan daya beli ini bertolak belakang dengan penurunan yang di hadapi outlet-outlet perbelanjaan. Gencaran marketplace dalam bentuk e-commerce membuat persaingan menjadi sangat kompetitif. Industri ritel modern pada kuartal terakhir 2019 dipengaruhi oleh tren belanja konsumen yang berubah dari offline menjadi online. Dampak perubahan gaya berbelanja tersebut kemudian di tambah dengan situasi pandemic yang membatasi gaya berbelanja offline. Situasi tersebut mendorong pelaku industri yang bergerak dalam bidang usaha pusat perbelanjaan, penyediaan jasa makanan dan jasa lainnya serta industri ritel untuk dapat menemukan breakthrough dalam meningkatkan penjualan pada outlet nya. Penelitian ini bertujuan untuk mengetahui faktor-faktor yang dapat meningkatkan impulse buying sehingga dapat memberikan landasan empiris dalam pengambilan keputusan oleh pelaku usaha ritel untuk dapat meningkatkan penjualannya secara intensif.

\section{Tinjauan Pustaka}

Impulse buying dapat terjadi ketika seorang individu mengalami dorongan yang kuat dan ia tidak dapat menahan dirinya (Solomon, 2019). Impulsive buying adalah suatu situasi ketika seorang konsumen membuat keputusan untuk membeli barang seketika berada di dalam toko. Karakteristik dari impulse buying behavior adalah relatif cepat dalam proses membuat keputusan dan bisa subjektif yang mendorong atau menguatkan keinginan untuk memiliki sesuatu dengan cepat (Dameyasani \& Abraham, 2013) Keputusan pembelian merupakan suatu proses pembelian berkaitan dengan keputusan merek, penjualan, waktu pembelian, dan cara pembayaran(Limento \& Cahyadi, 2020). Menurut Hyun Hee et al. (2015) pembelian secara impulsif sering kali muncul secara tibatiba, cepat, spontan, lebih mengarah pada emosional daripada rasional, lebih sering dianggap sebagai sesuatu yang buruk daripada sesuatu yang baik, dan konsumen cenderung merasa "out-of-control" ketika membeli barang secara impulsif. Sejalan dengan pendapat yang dikemukakan oleh Schiffman dan Wisenblit (2018) bahwa pembelian impulsif merupakan keputusan yang emosional dan dapat menjadi sangat kuat dan menjadi dasar dari motif pembelian yang dominan.

\section{Visual Merchandising adalah seni} atau keterampilan untuk menampilkan produk dengan semenarik mungkin sehingga calon pembeli tertarik untuk melihat produk atau bahkan membeli produk tersebut. Visual Merchandising adalah salah satu dari strategi yang menguntungkan yang dianggap sebagai satu dari penentu keberhasilan untuk toko ritel. Dalam Visual Merchandising, manajemen memastikan bahwa baik eksterior maupun interior toko mereka cukup menarik untuk menarik pelanggan. Baik eksterior dan interior dianggap memiliki dampak besar pada perilaku pembelian konsumen dan diamati untuk merangsang minat dan keinginan untuk membeli. Teknik ini juga membantu dalam penjualan jenis produk yang tepat ke jenis pelanggan yang tepat dengan mengembangkan daya tarik dan menampilkan produk yang sesuai (Pegler \& Kong, 2018).

Product involvement secara umum didefinisikan sebagai persepsi konsumen 
terhadap kepentingan dari suatu kategori produk yang didasarkan pada kebutuhan, nilai, serta minat konsumen (Bian \& Moutinho, 2011). Tingkat product involvement menentukan kedalaman, kompleksitas dan keluasan proses kognitif dan perilaku selama proses pemilihan konsumen, oleh karena itu keterlibatan produk adalah kerangka sentral, penting untuk memahami perilaku pengambilan keputusan konsumen dan komunikasi yang terkait (Law, Wong, \& Yip, 2012). Keterlibatan yang tinggi suatu produk diarahkan oleh motivasi yang tinggi oleh konsumen dan juga keterlibatan konsumen terhadap produk memiliki hubungan yang signifikan terhadap keputusan pembelian.

Menurut Liang (2012) product knowledge adalah persepsi konsumen terhadap produk tertentu, termasuk pengalaman sebelumnya menggunakan produk tersebut. Consumer product knowledge di persepsikan sebagai pemahaman pelanggan tentang produk, serta keyakinan konsumen terhadap produk tersebut. Product knowledge dapat diartikan sebagai pengetahuan yang dimiliki oleh konsumen mengenai produk atau jasa yang akan atau sudah dikonsumsi. Product knowledge adalah seluruh informasi yang terkandung dalam suatu produk/jasa yang diinterpretasikan oleh konsumen (Mothersbaugh, Hawkins, \& Kleiser, 2019). Pemahaman konsumen terhadap suatu produk atau jasa dipengaruhi tiga aspek dasar yaitu atribut produk, manfaat dari menggunakan produk atau jasa (baik dari manfaat fungsional maupun manfaat psikologis), dan nilai-nilai yang akan diperoleh konsumen dari mengonsumsi produk/jasa tersebut.

Gaya berbelanja menurut (Kotler \& Keller, 2015) adalah pola berbelanja seseorang yang diekspresikan dalam suatu aktivitas, minat dan opininya. Gaya berbelanja menggambarkan diri seseorang dalam berinteraksi dengan lingkungannya. Gaya berbelanja juga menggambarkan tentang seluruh pola seseorang dalam beraksi dan berinteraksi. Menurut Blackwell \& Miniard (2017) gaya berbelanja adalah konsep yang lebih baru dan lebih mudah terukur apabila dibandingkan dengan kepribadian yang didefinisikan sebagai pola konsumen menggunakan uang dan waktunya.

Social influence atau pengaruh sosial adalah proses di mana individu mengubah pikiran, perasaan, sikap, atau perilaku sebagai akibat dari interaksi dengan individu lain (Zagenczyk, Scott, Gibney, Murrell, \& Thatcher, 2010). Social influence terdiri dari cara di mana individu mengubah perilaku mereka untuk memenuhi tuntutan lingkungan sosial. Perilaku tersebut mengambil berbagai bentuk dan dapat dilihat dalam kesesuaian, sosialisasi, tekanan teman sebaya, kepatuhan, kepemimpinan, persuasi, penjualan, dan pemasaran. Social influence juga memainkan peranan penting dalam keputusan konsumen secara impulsif.

Emosi merupakan sebuah efek dari suasana hati yang merupakan faktor penting dalam pengambilan keputusan konsumen. Seseorang dapat menempatkan emosi tertentu, seperti rasa gembira, marah, kesukaan dan rasa sedih. Sebagai contoh, jika seseorang merasa sangat tidak menyenangkan dan terdorong, maka orang tersebut sedang mengalami emosi rasa marah. Sebaliknya, jika seseorang merasa sangat senang dan cukup pasif, maka orang tersebut mungkin sedang mengalami emosi rasa bahagia. Pada dasarnya pendekatan psikologi mengajukan pandangannya mengenai perilaku manusia bahwa perilaku manusia dipengaruhi oleh lingkungannya. Perasaan dapat dikonsepkan sebagai pengaruh positif emosi positif, yang mencerminkan sejauh mana seseorang merasa antusias, aktif, dan waspada (Branscombe \& Baron, 2016).

Jika membandingkan emosi positif dan negatif, konsumen dengan emosi positif melakukan pembelian impulsif lebih besar karena perasaan menjadi tidak dibatasi, keinginan untuk menghargai diri konsumen sendiri, dan tingkat energi yang lebih tinggi. Pada dasarnya pendekatan psikologi mengajukan pandangannya mengenai perilaku manusia bahwa perilaku manusia dipengaruhi oleh lingkungannya. Untuk mengukur emosi yang dikaitkan dengan konsumsi atau di dominasi lainnya, Dengan demikian, semakin besar emosi positif pelanggan, semakin besar keinginan untuk membeli impulsif (Verhagen \& Van Dolen, 2011). 
Hubungan Visual Merchandising terhadap Positive Emotion

Penelitian yang dilakukan oleh (Law et al., 2012) menunjukkan bahwa subjek yang berpartisipasi memiliki dua sudut pandang ketika mengevaluasi tampilan toko visual, yang mencakup aspek utilitarian dan hedonis. Aspek utilitarian berkaitan dengan kebutuhan aktual konsumen, seperti penurunan kualitas pakaian, perubahan musim dan kesempatan. Aspek hedonis menemukan bahwa citra wanita yang dirasakan mengatur interpretasi konsumen dan penerimaan tampilan visual. Sehingga para ritel menghabiskan banyak upaya dalam menciptakan identitas unik melalui strategi visual merchandising yang berbeda untuk memberikan emosi positif bagi konsumen, yang bertujuan untuk meningkatkan niat beli. Hasil dari penelitian tersebut menyatakan bahwa visual merchandising yang terdapat pada situs produk dapat mempengaruhi emosi pada responden tersebut.

\section{Hubungan Product Involvement terhadap Positive Emotion}

Tingkat keterlibatan produk yang tinggi menyebabkan konsumen lebih memungkinkan untuk mengalami emosi positif misalnya merasa bersemangat dan puas selama berbelanja. Penelitian (Hyun Hee et al., 2015) menyatakan bahwa keterlibatan produk dapat meningkatkan pengalaman emosi ketika berbelanja. Keterlibatan yang dialami konsumen akan dapat menyebabkan meningkatnya emosi positif karena konsumen merasa puas dan senang terhadap kualitas produk yang ditawarkan atau dijual. Hasil penelitian tersebut menunjukkan bahwa keterlibatan produk memiliki efek kausal positif pada emosi positif. Penelitian yang dilakukan menyatakan bahwa Product Involvement berpengaruh positif dan signifikan terhadap Positive Emotion.

\section{Hubungan Product Knowledge terhadap Positive Emotion.}

Penelitian yang menggunakan variabel pengetahuan produk pernah ditulis oleh (Harmancioglu, Finney, \& Joseph, 2009), hasil penelitian tersebut menunjukkan bahwa tingkat pengetahuan produk konsumen berpengaruh pada emosi positif. hasil penelitian dalam jurnal tersebut menunjukkan bahwa emosi positif dipengaruhi oleh beberapa hal, dan dapat memicu timbulnya pembelian secara impulsif.

\section{Hubungan Shopping Lifestyle terhadap Positive Emotion.}

Shopping lifestyle merupakan gaya hidup yang dilakukan seseorang untuk mengekspresikan diri dengan pola tindakan menghabiskan waktu dan uang, yang dapat digunakan untuk membedakan sifat dan karakteristik seseorang melalui gaya berbelanja (Blackwell \& Miniard, 2017; Kotler \& Keller, 2015). Dengan adanya ketersediaan waktu konsumen akan memiliki banyak waktu untuk berbelanja dan dengan uang konsumen akan memiliki daya beli yang tinggi. Hal tersebut tentu berkaitan dengan keterlibatan konsumen untuk membeli suatu produk juga mempengaruhi pembelian impulsif. Shopping lifestyle dapat memengaruhi adanya emosi positif pada diri seseorang. Gaya hidup berbelanja yang telah menjadi kebutuhan bagi sebagian besar masyarakat akan membentuk sebuah emosi positif apabila kebutuhan tersebut dapat dipenuhi. Mereka akan merasa senang ketika kebutuhannya akan gaya hidup berbelanja sudah terpenuhi.

\section{Hubungan Social Influence terhadap Positive Emotion.}

Menurut Wang dan Chou (2014), pengaruh sosial mengacu pada bagaimana orang lain mempengaruhi keputusan perilaku seseorang. Pengaruh sosial terkait dengan tekanan eksternal (dari orang-orang penting dalam hidup seseorang, seperti keluarga, teman, dan supervisor di tempat kerja). Pengaruh sosial adalah sejauh mana jaringan sosial mempengaruhi perilaku masyarakat melalui pesan dan sinyal dari orang lain yang memfasilitasi pembentukan nilai masyarakat yang dirasakan dari sistem teknologi. Hal ini diperkuat dengan penelitian yang dilakukan oleh Eckman dan Yan (2012) menunjukkan bahwa rangsangan yang disebabkan oleh lingkungan sosial berpengaruh positif terhadap respons emosi positif dari konsumen.

\section{Hubungan Visual Merchandising terhadap Impulse buying.}


Visual Merchandising merupakan pengaruh keadaan toko atau karakter keadaan toko, seperti arsitektur, tata letak, penanda, pemajangan, warna, pencahayaan, temperatur, musik serta aroma, secara menyeluruh yang akan menciptakan citra dalam benak konsumen suatu karakteristik atau elemen yang harus dipertimbangkan dan sangat penting bagi setiap pelaku bisnis. Suasana toko berperan sebagai salah satu faktor yang menentukan kenyamanan konsumen dan membuat konsumen ingin berlama-lama berada di dalam toko tersebut. Adanya persaingan yang semakin ketat dalam bisnis ritel menuntut setiap bisnis ritel modern perlu meningkatkan kekuatan yang ada dalam perusahaannya dengan cara memunculkan perbedaan atau keunikan yang dimiliki perusahaan dibandingkan dengan pesaing untuk dapat menarik minat beli konsumen.

Beyhan dan Laurent (2012) menjelaskan pentingnya memiliki tampilan yang menarik bisa sangat penting bagi toko ritel. Bahkan, pelanggan akan lebih memperhatikan tampilan dalam waktu tiga hingga delapan detik yang merupakan waktu yang dibutuhkan bagi mereka untuk membangun minat pada produk yang ditampilkan sehingga memungkinkan untuk terjadinya pembelian secara impulsif.

\section{Hubungan Product Involvement terhadap Impulse buying.}

Lloyd et al., (2014) melakukan penelitian mengenai pengaruh product involvement terhadap impulse buying dengan dua produk, yaitu musik dan pakaian terhadap 117 sampel. Hasil dari penelitian yang dilakukannya yaitu product involvement berpengaruh positif terhadap impulse buying. Karena semakin tinggi tingkat keterlibatan produk konsumen atau product involvement, maka semakin tinggi perilaku pembelian secara impuls atau impulse buying, penelitian ini selanjutnya digunakan regresi berganda hierarki untuk menguji hubungan antara keterlibatan produk konsumen dan perilaku pembelian impulsif, yaitu saat product knowledge lebih tinggi karena product involvement konsumen yang lebih tinggi, akan mendorong pembelian secara impuls (Liang, 2012). Menurut Jones et al. (2003), pembelian impuls pada produk tertentu adalah hasil dari keterlibatan produk dan kecenderungan pembelian impuls dari pembelanja.

\section{Hubungan Product Knowledge terhadap Impulse buying.}

Harmancioglu et al., (2014) melakukan penelitian terkait pengaruh product knowledge terhadap impulse buying, Hasil dari penelitian tersebut menunjukkan bahwa product knowledge dan karakteristik konsumen (emosi dan harga diri) meningkatkan impulse buying dan niat beli. Selain itu, hipotesis yang ada menunjukkan bahwa impulse buying intention, product knowledge dan kegembiraan mempengaruhi impulse buying behavior (Kapoor dan Kulshrestha, 2009). Menurut Liang (2012) dalam penelitiannya menunjukkan bahwa product knowledge dan impulse buying behavior berkorelasi positif, dan meningkat signifikan secara statistik.

\section{Hubungan Shopping Lifestyle terhadap Impulse buying.}

Ablocki dan Kanter (2011) menjelaskan bahwa gaya hidup belanja menggambarkan cara yang dipilih oleh seseorang untuk mengalokasikan pendapatan, baik dari segi alokasi dana untuk berbagai produk dan layanan, seperti alternatif tertentu dalam perbedaan kategori yang sama. Sedangkan impulse buying didefinisikan sebagai tindakan membeli yang sebelumnya tidak diakui secara sadar sebagai hasil dari suatu pertimbangan atau niat membeli yang terbentuk sebelum memasuki toko (Mowen dan Michael, 2008).

Ketika sebagian besar masyarakat memiliki shopping lifestyle yang tinggi maka hal tersebut akan mendorong mereka untuk melakukan impulse buying. Hal tersebut terjadi karena terdapat keinginan untuk memenuhi kebutuhan gaya hidup mereka terhadap fashion yang semakin berkembang, sehingga ketika mereka melakukan kegiatan berbelanja akan muncul perilaku impulse buying. Tauseef (2011) menemukan bahwa shopping lifestyle dan impulse buying behavior memiliki hubungan tetapi hanya dalam kasus pembeli impuls. Studi ini juga menyatakan bahwa pembeli impuls berada di antara pengukuran yang digunakan oleh para peneliti, menunjukkan bahwa pembeli tidak akan 
memilih merek pertama yang mereka temukan di pusat perbelanjaan.

\section{Hubungan Social Influence terhadap Impulse}

\section{buying.}

Faktor situasional adalah rangsangan eksternal yang mempengaruhi konsumen pada saat pembelian dengan dorongan hati (Kacen et al., 2012). Biasanya itu tidak di bawah kendali konsumen tetapi pengaruh langsung pada perilaku pembelian impulsif. Faktor situasional diusulkan terdiri dari lima

dimensi dan masing-masing dimensi yaitu lingkungan toko (Liao et al., 2009), pengaruh sosial (Mattila dan Wirtz, 2008), waktu (Foroughi et al., 2012), uang (Foroughi et al. , 2012), dan kartu kredit yang tersedia (Foroughi et al. , 2012) memiliki hubungan dengan perilaku pembelian impulsif. Selain itu, pengaruh sosial juga mempengaruhi konsumen untuk terlibat dalam perilaku pembelian impulsif (Luo, 2005).

\section{Hubungan Positive Emotion terhadap Impulse buying.}

Penelitian yang sebelumnya dilakukan oleh Park et al. (2006) juga menjelaskan bahwa adanya hubungan yang signifikan antara positives emotion dengan impulse buying. Menurut literatur yang dilakukan oleh Yanhong Chen et al., (2018) menyatakan bahwa perilaku pembelian impulsif konsumen sering ditandai dengan aktivitas emosional yang tinggi dan perilaku ini terjadi ketika individu mengalami emosi positif yang kuat.

Chang, Yan dan Eckman (2014) dalam jurnalnya juga menjelaskan bahwa emosi positif konsumen mempengaruhi perilaku pembelian konsumen secara impulsif yang disertai dengan perasaan senang serta secara langsung dipengaruhi oleh emosi positif konsumen. Beberapa ahli dan penelitian sebelumnya telah menguji apakah ketika konsumen yang memiliki emosi positif yang besar akan lebih mempengaruhi pembelian impulsif. Sehingga dapat dinyatakan bahwa semakin tinggi emosi positif konsumen, semakin tinggi pengaruhnya terhadap pembelian impulsif.

Berdasarkan tinjauan pustaka dan penelitian terdahulu seperti yang diuraikan di atas, maka hipotesis yang akan dikembangkan dalam penelitian ini adalah:
$\mathrm{H}_{1}$ : $\quad$ Diduga terdapat pengaruh positif Visual Merchandising terhadap Positive Emotion

$\mathrm{H}_{2}$ : Diduga terdapat pengaruh positif Product Involvement terhadap Positive Emotion

$\mathrm{H}_{3}$ : $\quad$ Diduga terdapat pengaruh positif Product Knowledge terhadap Positive Emotion

$\mathrm{H}_{4}$ : $\quad$ Diduga terdapat pengaruh positif Shopping Lifestyle terhadap Positive Emotion

$\mathrm{H}_{5}$ : $\quad$ Diduga terdapat pengaruh positif Social Influence terhadap Positive Emotion

$\mathrm{H}_{6}$ : $\quad$ Diduga terdapat pengaruh positif Visual Merchandising terhadap Impulse buying

$\mathrm{H}_{7}$ : Diduga terdapat pengaruh positif Product Involvement terhadap Impulse buying

$\mathrm{H} 8$ : $\quad$ Diduga terdapat pengaruh positif Product Knowledge terhadap Impulse buying

$\mathrm{H}_{9}$ : Diduga terdapat pengaruh positif Shopping Lifestyle terhadap Impulse buying

$\mathrm{H}_{10}$ : Diduga terdapat pengaruh positif Social Influence terhadap Impulse buying

$\mathrm{H}_{11}$ : Diduga Positif Emotion memediasi hubungan terhadap Impulse buying.

\section{Metode Penelitian}

Desain penelitian yang ditetapkan dalam penelitian ini adalah riset kausal dengan kerangka penelitian adalah jalur (path) yang merupakan perluasan dari analisis regresi yang digunakan untuk menerangkan akibat langsung dan tidak langsung seperangkat variabel, sebagai variabel penyebab terhadap seperangkat variabel lain yang merupakan variabel akibat.

Dalam penelitian ini, populasi yang digunakan adalah konsumen on site pada pusat-pusat perbelanjaan di JABODETABEK. Metode sampel yang digunakan dalam penelitian ini adalah Non-Probability Sampling, yaitu tiap responden yang memenuhi kriteria populasi tidak memiliki kesempatan atau peluang yang sama untuk dipilih menjadi sampel (Malhotra, Nunan, \& Birks, 2017). Ukuran sample sebanyak 360 responden yang 
ditentukan dengan mengacu pada rule of thumb dari SEM.

Teknis analisis data yang digunakan dalam penelitian ini adalah teknik Structural Equation Model (SEM) dengan metode Partial Least Square. SEM menurut Jöreskog et al., (2016) merupakan sebuah teknik statistik multivariat yang menggabungkan aspek-aspek dalam regresi berganda (yang bertujuan untuk menguji hubungan dependent) dan analisis faktor (yang menyajikan unmeasured concepts factors with multiple variables) yang dapat digunakan untuk memperkirakan serangkaian hubungan dependen yang saling mempengaruhi secara bersama-sama. Sedangkan Structural Equation Model Covariance Based (SEM-PLS) merupakan pendekatan pemodelan kausal dengan tujuan memaksimalkan variabel dari variabel endogen (dependent) yang dapat dijelaskan oleh variabel eksogen (independent).

Model serta hipotesis yang digunakan dalam penelitian digambarkan dalam diagram berikut ini:

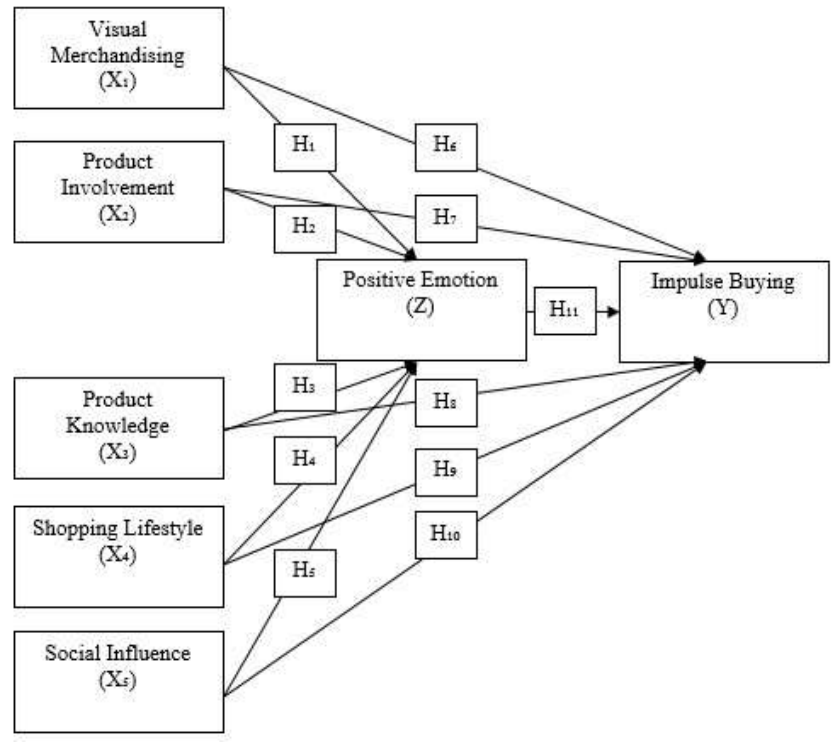

\section{Hasil Penelitian}

Jumlah kuesioner yang dikirim sebanyak 360 mendapatkan hasil dengan demografi responden menunjukkan karakteristik terbesar pada: jenis kelamin laki-laki, pendidikan SMA/SMK, rentang usia antara 21-24, dengan pekerjaan karyawan swasta, frekuensi belanja sebanyak 2 kali dalam seminggu dan pengeluaran rutin per bulan >Rp.3.000.000.

\section{Pengukuran Inner Model}

Uji Validitas dan Uji reliabilitas dilakukan dengan menghitung validitas konvergen. Bisa dilihat pada lampiran 5 . Validitas konvergen diketahui melalui nilai loading factor dan Average Variance Extracted (AVE). Suatu instrument dikatakan memenuhi pengujian validitas konvergen apabila memiliki loading factor dan Average Variance Extracted (AVE) di atas 0.5. Hasil pengujian validitas konvergen bahwa semua indicator menghasilkan nilai loading factor bernilai lebih dari 0,5. Dan juga semua variabel menghasilkan nilai Average Variance Extracted (AVE) yang lebih besar dari 0,5 . Dengan demikian berdasarkan

validitas konvergen semua indikator tersebut dinyatakan valid. Sedangkan pengukuran reliabilitas menggunakan kriteria pengujian composite reliability bernilai lebih besar dari 0.7 maka konstruksi tersebut dinyatakan reliabel. Kesimpulan dari uji inner model sebagai berikut:

Tabel 1

Composite Reliability dan AVE

\begin{tabular}{lll}
\hline Variabel & $\begin{array}{l}\text { Composite } \\
\text { Reliability }\end{array}$ & $\begin{array}{l}\text { Average } \\
\text { Extracted (AVE) }\end{array}$ \\
\hline $\begin{array}{l}\text { Impulse } \\
\text { Buying }\end{array}$ & 0.824 & 0.701 \\
$\begin{array}{l}\text { Positive } \\
\text { Emotions }\end{array}$ & 0.813 & 0.685 \\
$\begin{array}{l}\text { Product } \\
\text { Involvemen } \\
\text { t }\end{array}$ & 0.837 & 0.72 \\
$\begin{array}{l}\text { Product } \\
\text { Knowledge } \\
\text { Shopping }\end{array}$ & 0.824 & 0.61 \\
$\begin{array}{l}\text { Influence } \\
\text { Shopping }\end{array}$ & 0.814 & 0.594 \\
Lifestyle & 0.615 & 0.689 \\
$\begin{array}{l}\text { Visual } \\
\text { Merchandis } \\
\text { ing }\end{array}$ & 0.785 & 0.646 \\
\hline
\end{tabular}

\section{Pengukuran Outer Model}

Pengujian signifikansi digunakan untuk menguji ada tidaknya pengaruh variabel eksogen terhadap variabel endogen. Hasil pengujian signifikansi dan model dapat diketahui melalui tabel berikut: 
Tabel 2

Direct Effect

\begin{tabular}{llll}
\hline Direct Effect & & $\begin{array}{l}\text { Original } \\
\text { Sample (0) }\end{array}$ & $\begin{array}{l}\text { P } \\
\text { Valu } \\
\text { es }\end{array}$ \\
\hline $\begin{array}{l}\text { Positive Emotions } \\
\text { Impulse Buying }\end{array}$ & $->$ & 0.379 & 0.000 \\
$\begin{array}{l}\text { Product Involvement } \\
\text { Impulse Buying }\end{array}$ & $->$ & 0.05 & 0.182 \\
$\begin{array}{l}\text { Product Involvement } \\
\text { Positive Emotions }\end{array}$ & $->$ & -0.016 & 0.732 \\
$\begin{array}{l}\text { Product Knowledge } \\
\text { Impulse Buying }\end{array}$ & $->$ & 0.099 & 0.035 \\
$\begin{array}{l}\text { Product Knowledge } \\
\text { Positive Emotions } \\
\text { Shopping Influence }\end{array}$ & $->$ & 0.088 & 0.052 \\
$\begin{array}{l}\text { Impulse Buying } \\
\text { Shopping Influence }\end{array}$ & $->$ & 0.444 & 0.000 \\
$\begin{array}{l}\text { Positive Emotions } \\
\text { Shopping Lifestyle }\end{array}$ & $->$ & -0.004 & 0.000 \\
$\begin{array}{l}\text { Impulse Buying } \\
\text { Shopping Lifestyle } \\
\text { Positive Emotions }\end{array}$ & $->$ & -0.018 & 0.701 \\
$\begin{array}{l}\text { Visual Merchandising } \\
\text { Impulse Buying } \\
\text { Visual Merchandising }\end{array}$ & $->$ & 0.133 & 0.01 \\
Positive Emotions & & 0.214 & 0.000 \\
\hline
\end{tabular}

Tabel 3

Indirect Effect

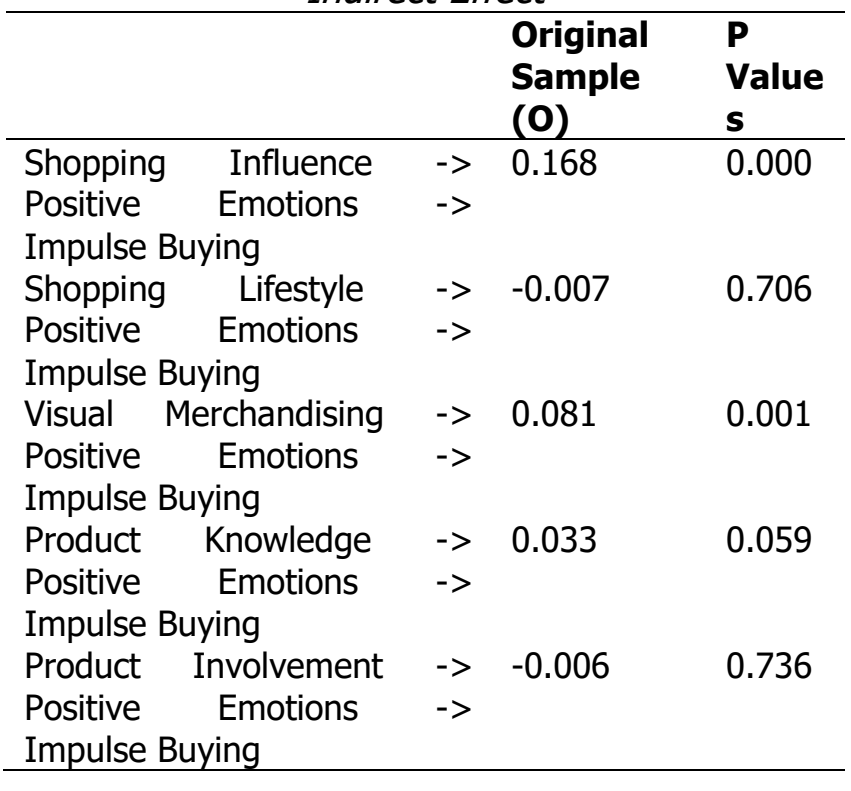

\section{Hubungan Visual Merchandising terhadap Positive Emotion.}

Hasil pengujian ini menunjukkan bahwa

Visual Merchandising berpengaruh signifikan terhadap Positive Emotion. Dapat disimpulkan bahwa 360 konsumen pada pusat perbelanjaan merasakan emosi positif seperti rasa senang ketika mereka melihat Visual Merchandising yang diterapkan oleh outlet, yaitu penempatan produk dan peralatan untuk menunjang Visual Merchandising yang ditempatkan secara tertata dan proporsional dan juga kebersihan dari outlet pada pusat perbelanjaan juga sangat mempengaruhi rasa senang konsumen ketika mengunjungi outlet tersebut. Hasil penelitian ini mendukung penelitian sebelumnya yang menyatakan bahwa Visual Merchandising memiliki efek pada terhadap emosi positif konsumen pada outlet perbelanjaan di Korea.

\section{Hubungan Product Involvement terhadap Positive Emotion.}

Hasil pengujian ini menunjukkan bahwa Product Involvement tidak berpengaruh signifikan terhadap Positive Emotion pada konsumen outlet perbelanjaan. Artinya persepsi konsumen terhadap kepentingan dari suatu kategori produk saat berbelanja di pusat-pusat perbelanjaan tidak didasarkan pada kebutuhan, nilai maupun minat yang tinggi sehingga memunculkan emosi positif saat berbelanja. Hal ini dapat disadari mengingat bahwa pengumpulan data primer dilakukan saat pemerintah menerapkan pembatasan sosial karena pandemi virus COVID 19.

\section{Hubungan Product Knowledge terhadap Positive Emotion.}

Hasil pengujian ini menunjukkan bahwa Product Knowledge tidak berpengaruh signifikan terhadap Positive Emotion. Artinya persepsi konsumen pusat-pusat perbelanjaan saat berbelanja tidak didasari oleh kesadaran atau pemahaman pelanggan tentang produk, serta keyakinan konsumen dalam produk atau jasa yang di tawarkan pada outlet - outlet. Kurangnya pemahaman saat berbelanja inilah yang membuat konsumen yang berbelanja tidak mendapatkan emosi positive di pusatpusat perbelanjaan tersebut.

\section{Hubungan Shopping Lifestyle terhadap Positive Emotion.}

Hasil pengujian ini menunjukkan bahwa Shopping Lifestyle tidak berpengaruh signifikan terhadap Positive Emotion. Artinya konsumen tidak menjadikan kegiatan berbelanja di pusatpusat perbelanjaan sebagai gaya hidup yang pada akhirnya tidak dapat menimbulkan emosi 
positif selama mengunjungi pusat-pusat perbelanjaan di Indonesia. Kesimpulan ini berkaitan erat di mana saat pengumpulan data primer berlangsung sedang diterapkan PSBB, sehingga konsumen menganggap kegiatan berbelanja secara langsung di pusat perbelanjaan bukan cara yang tepat untuk bersosialisasi.

\section{Hubungan Social Influence terhadap Positive Emotion.}

Hasil pengujian ini menunjukkan bahwa Social Influence berpengaruh signifikan terhadap Positive Emotion. Responden yang sebagian besar adalah mahasiswa berusia 2124 tahun memiliki karakteristik yang mudah dipengaruhi, contohnya adalah mudah dipengaruhi oleh lingkungan sekitar mereka dan mereka dengan mudah untuk mendengarkan pendapat orang lain terhadap kegiatan berbelanja di pusat perbelanjaan sehingga mereka merasa penasaran kepada kegiatan berbelanja pada saat Pemerintah menerapkan PSBB. Informasi yang kontradiktif antara himbauan jaga jarak (Social Distancing) dengan kenyataan bahwa masih banyaknya tempat berkumpul seperti pusat perbelanjaan, café, restorant yang masih buka menjadi pemicu bagi klaster demografi ini untuk mendapatkan emosi positif melalui kegiatan berbelanja secara langsung di pusat-pusat perbelanjaan.

\section{Hubungan Visual Merchandising terhadap Impulse Buying}

Hasil pengujian ini menunjukkan bahwa Visual Merchandising berpengaruh signifikan terhadap Impulse Buying. Artinya bahwa Visual Merchandising atau tampilan produk yang dilakukan oleh outlet-outlet di pusat perbelanjaan dapat mempengaruhi untuk seketika berbelanja secara impulsif.

Hasil penelitian ini mendukung penelitian dan sesuai dengan yang dilakukan oleh Mehta \& Chugan (2015), yang menyatakan bahwa Visual Merchandising memiliki pengaruh terhadap Impulse Buying.

\section{Hubungan Product Involvement terhadap Impulse Buying.}

Hasil pengujian ini menunjukkan bahwa Product Involvement tidak berpengaruh signifikan terhadap Impulse Buying. Artinya persepsi konsumen terhadap kepentingan dari suatu kategori produk saat berbelanja di pusatpusat perbelanjaan tidak didasarkan pada kebutuhan, nilai maupun minat yang tinggi sehingga memunculkan keinginan untuk berbelanja secara impulsif.

Hasil penelitian ini tidak mendukung penelitian yang dilakukan oleh Liang (2012), yang menyatakan bahwa Product Involvement memiliki pengaruh terhadap Impulse Buying.

\section{Hubungan Product Knowledge terhadap Impulse Buying.}

Hasil pengujian ini menunjukkan bahwa Product Knowledge berpengaruh signifikan terhadap Impulse Buying. Artinya konsumen yang berbelanja di pusat-pusat perbelanjaan melakukan kegiatan berbelanja secara impulsif karena mereka pernah mencoba atau mereka tertarik karena manfaat yang ditawarkan oleh produk maupun jasa tersebut.

Hasil penelitian ini mendukung penelitian yang dilakukan oleh Liang (2012), yang menyatakan bahwa Product Involvement memiliki pengaruh terhadap Impulse Buying.

\section{Hubungan Shopping Lifestyle terhadap Impulse Buying.}

Hasil pengujian ini menunjukkan bahwa Shopping Lifestyle tidak berpengaruh signifikan terhadap Impulse Buying. Artinya responden tidak berbelanja secara impulsif karena untuk memenuhi keinginan atau kebutuhan saja namun karena faktor lain yang menyebabkan responden berbelanja. Temuan penelitian ini tidak mendukung penelitian yang dilakukan oleh Rahmawati (2018) yang menunjukkan Shopping lifestyle berpengaruh positif dan signifikan terhadap Impulse Buying pada mahasiswa di Yogyakarta.

\section{Hubungan Social Influence terhadap Impulse Buying.}

Hasil pengujian ini menunjukkan bahwa Social Influence berpengaruh signifikan terhadap Impulse Buying pada kegiatan berbelanja di pusat-pusat perbelanjaan. Artinya konsumen berbelanja di pusat-pusat perbelanjaan karena terpengaruh oleh lingkungan sekitar maupun menerima pendapat dari orang lain. Temuan penelitian ini juga 
diperkuat bahwa karena kondisi social yang telah lama dibatasi karena adanya Pandemi, sehingga saat konsumen mendapatkan informasi mengenai kegiatan berbelanja offline maka fakta ini memicu konsumen lainnya turut serta dalam aktivitas pemenuhan kebutuhan ini. Pengaruh yang intens ini ternyata berpengaruh positif di mana artinya konsumen seketika berbelanja karena pengaruh tersebut.

Hal ini mendukung penelitian yang dilakukan oleh Branscombe \& Baron (2016) yang menunjukkan Social Influence berpengaruh secara signifikan terhadap Impulse Buying.

\section{Hubungan Positive Emotion terhadap Impulse Buying.}

Hasil pengujian ini menunjukkan bahwa

Positive Emotion berpengaruh signifikan terhadap Impulse Buying. Responden yang sebagian besar mahasiswa berusia $21-24$ tahun memiliki karakteristik yang senang dalam berbelanja karena sudah menjadi gaya hidup yang lebih mementingkan penampilan, dengan didominasi laki-laki. Berdasarkan uji statistik, dimensi Positive Emotion yang paling besar adalah merasakan puas. Temuan ini dapat diartikan bahwa konsumen merasakan puas saat berbelanja tanpa direncanakan terlebih dahulu atau berbelanja secara impulsif. Hasil penelitian ini mendukung dan sejalan dengan penelitian yang dilakukan oleh Listriani \& Wahyono (2012) juga menunjukkan bahwa Positive Emotion memiliki pengaruh signifikan terhadap Impulse Buying.

\section{Kesimpulan}

Dari hasil pembahasan penelitian, dapat diperoleh temuan penelitian yaitu bahwa pengaruh paling besar yang dapat membuat konsumen berbelanja di pusat perbelanjaan adalah social influence, hal ini berarti untuk dapat mencapai tujuan penelitian ini, pelaku industri harus dapat memprioritaskan faktor social influence dalam menciptakan positive emotion pada konsumen sehingga dapat mempengaruhi perilaku belanja secara impulsif. Perilaku berbelanja secara impulsif perlu di prioritaskan oleh pelaku industri termasuk tenant maupun outlet di dalamnya agar dapat meningkatkan penjualan secara intensif dan memicu pertumbuhan ekonomi mikro yang lebih baik.

Pengaruh social influence ini dapat di sinergikan dengan faktor kedua, yaitu visual merchandising yang berpengaruh dalam meningkatkan positive emotion dalam berbelanja sehingga dapat meningkatkan perilaku berbelanja secara impulsif. Penataan informasi produk maupun jasa yang baik serta layout yang tepat secara empiris terbukti dapat meningkatkan positive emotion dan pembelian secara impulsif dalam berbelanja. Kedua faktor ini harus menjadi prioritas utama bagi pelaku industri, karena telah terbukti secara empiris berpengaruh terhadap pembelian secara impulsif sehingga dapat meningkatkan penjualan dalam waktu singkat.

Penelitian ini dilaksanakan dalam kurun waktu yang relatif singkat dan menggunakan variabel serta hipotesis yang di bangun berdasarkan penelitian terdahulu saja. Keterbatasan penelitian tersebut dapat saja mempengaruhi kesimpulan yang tidak komprehensif. Penelitian lanjutan diharapkan dapat memperbesar cakupan sehingga temuan yang lebih komprehensif dapat dihasilkan.

\section{Daftar Pustaka}

Bian, X., \& Moutinho, L. (2011). The role of brand image, product involvement, and knowledge in explaining consumer purchase behaviour of counterfeits: Direct and indirect effects. European Journal of Marketing, 45(1), 191-216. https://doi.org/10.1108/0309056111109 5658

Blackwell, R. D., \& Miniard, P. W. (2017). Consumer Behavior (10th ed.). New Delhi: Cengage India.

Branscombe, N. R., \& Baron, R. A. (2016). Social Psychology (14th ed.). New York: Pearson.

Dameyasani, \& Abraham, J. (2013). Impulsive Buying, Cultural Values Dimensions, and Symbolic Meaning of Money: A Study on College Students in Indonesia's Capital City and Its Surrounding. International Journal of Research Studies in Psychology, 2(3), 35-32. https://doi.org/https://doi.org/10.5861/i jrsp.2013.374

Harmancioglu, N., Finney, R. Z., \& Joseph, M. 
(2009). Impulse purchases of new products: An empirical analysis. Journal of Product and Brand Management, 18(1), 27-37. https://doi.org/10.1108/1061042091093 3344

Hyun Hee, P., Jeon, J. O., \& Sullivan, P. (2015). How Does Visual Merchandising in Fashion Retail Stores Affect Consumers' Brand Attitude and Purchase Intention? International Review of Retail, Distribution and Consumer Research, 25(1), 87-104. https://doi.org/https://doi.org/10.1080/ 09593969.2014.918048

Jöreskog, K. G., Olsson, U. H., \& Wallentin, F. Y. (2016). Multivariate Analysis with LISREL (1st ed.). New York: Springer.

Kotler, P., \& Keller, K. (2015). Marketing Management (15th ed.). New York: Pearson.

Law, D., Wong, C., \& Yip, J. (2012). How does visual merchandising affect consumer affective response?: An intimate apparel experience. European Journal of Marketing, 46(1), 112-133. https://doi.org/10.1108/0309056121118 9266

Liang, Y.-P. (2012). The Relationship between Consumer Product Involvement, Product Knowledge and Impulsive Buying Behavior. Procedia - Social and Behavioral Sciences, 5703), 325-330. https://doi.org/10.1016/j.sbspro.2012.0 9.1193

Limento, N. Y., \& Cahyadi, L. (2020). Analisis Pengaruh Brand Loyalty, Brand Association, Brand Awareness Dan Perceived Quality Terhadap Keputusan Pembelian. JCA of Economics, 01(02).

Listriani, \& Wahyono. (2012). The Role of Positive Emotion in Increasing Impulse Buying. Management Analysis Journal, 1(2), 120-128.

Malhotra, N. K., Nunan, D., \& Birks, D. F. (2017). Marketing Research an Applied Approach (5th ed.). New York: Pearson.

Mehta, N., \& Chugan, P. K. (2015). Visual Merchandising and Purchasing Behavior for High Involvement Products: A Study of Electronics Outlets. International Journal of Logistics \& Supply Chain
Management Perspectives, 4(2), 16431654.

Mothersbaugh, D., Hawkins, D., \& Kleiser, S. B. (2019). Consumer Behavior: Building Marketing Strategy (14th ed.). Manhattan: McGraw-Hill Education.

Pegler, M. M., \& Kong, A. (2018). Visual Merchandising and Display: Studio Instant Access (7th ed.). New York: Fairchild Books.

Schiffman, L., \& Wisenblit, J. (2018). Consumer Behavior (What's New in Marketing) (12th ed.). London: Pearson.

Solomon, M. R. (2019). Consumer Behavior (13th ed.). Harlow: Pearson Education.

Verhagen, T., \& Van Dolen, W. (2011). The influence of online store beliefs on consumer online impulse buying: A model and empirical application. Information and Management, 48(8), 320-327.

https://doi.org/10.1016/j.im.2011.08.00 1

Zagenczyk, T. J., Scott, K. D., Gibney, R., Murrell, A. J., \& Thatcher, J. B. (2010). Social influence and perceived organizational support: A social networks analysis. Organizational Behavior and Human Decision Processes, 111(2), 127-138. https://doi.org/10.1016/j.obhdp.2009.11 .004 